\title{
Multifunctional oligoetherols and polyurethane foams with carbazole ring
}

\author{
Renata Lubczak \\ Rzeszów University of Technology, Department of Organic Chemistry, al. Powstańców Warszawy 6, 35-959 Rzeszów, Poland \\ Corresponding author: e-mail: rlubczak@prz.rzeszow.pl
}

\begin{abstract}
A new method of preparation of multifunctional oligoetherols containing carbazole ring is presented. The oligoetherols were obtained in the reaction of 9-(2,3-epoxypropyl)carbazole with sorbitol and oxiranes like ethylene and propylene oxide. The structure of obtained oligoetherols was determined by IR, H-NMR and MALDI-ToF spectroscopies. Physical properties of the products render them good candidates for preparing polyurethane foams. The foams were obtained and their properties were examined. It has been found that the foams are rigid at room temperature and their apparent density was $50-70 \mathrm{~kg} / \mathrm{m}^{3}$. The water uptake was low, maximum to 6.5 mass $\%$. Obtained foams have high thermal resistance. Dynamic thermal analysis of these foams showed that $5 \%$ mass loss was initiated at $250-300^{\circ} \mathrm{C}$, while temperature of $50 \%$ mass loss was $370-404^{\circ} \mathrm{C}$. Concomitantly the increase of compression strength was observed.
\end{abstract}

Keywords: carbazole, sorbitol, hydroxyalkylation, oligoetherols, thermal stability of foams.

\section{INTRODUCTION}

The progress in research on synthesis and properties of new polymeric materials containing carbazole ring has been observed in recent years. Carbazole and its derivatives are used in chemistry and technology of polymers, dyes, pesticides, drugs, surfactants, stabilizers and other additives for plastics ${ }^{1-7}$. Some of derivatives were demonstrated to have unique physical properties like photo- and electroluminescence, liquid crystallinity, electric conductivity, and non-linear optics ${ }^{8-14}$. Polymers with carbazole ring fall into two categories, namely those with carbazole group in main chain and inside chain. In the latter group, some polymers contain carbazole attached by nitrogen and others in which the carbazole ring is bonded via carbon. The side chain length between main chain and carbazole is crucial for physicochemical properties like phase transition temperature, solubility in organic solvents, the ability of formation of charge transfer complexes, and non-linear optical properties. Polymers containing carbazole in main chain are usually obtained from monomers with two functional groups attached to the ring. These polymers, having the system of conjugated $\pi$ bonds posses advantageous electrooptical properties ${ }^{15}$. The macrocyclic composed of eight carbazole units in main chain indicate useful electroluminescence ${ }^{16}$. The syntheses of multifunctional oligoetherols (OGE) with carbazole ring was not reported till now. High thermal resistance of carbazole makes it useful substrate to increase thermal stability of OGE and polymers obtained from them, like polyurethanes (PU) and polyesters ${ }^{17-20}$. Thus, the linear OGE were obtained from carbazole and epichlorohydrin leading to 9-(2,3-epoxypropyl)carbazole (EPC) followed by epoxide ring opening upon reaction with water or ethylene glycol or on alternative route by reaction of carbazole with ethylene chloride and further conversion of semiproduct by dietanolamine to give diol, which was finally converted to oligoetherol by reaction with oxirane axcess ${ }^{18,19}$. All obtained OGE showed high thermal resistance. When propylene glycol was replaced by 3-(9-carbazoil)propane-1,2-diol in synthesis of polyester resin, the obtained polymer indicated remarkable increase of thermal stability ${ }^{21}$.

The PU foams obtained till now were thermally stable up to long storage at $150^{\circ} \mathrm{C}$. The exposure of foams to $200^{\circ} \mathrm{C}$ resulted in dimension and shape changes of samples. Probably the reason was too low functionality of used OGE with carbazole ring which were three-functional. Therefore, described synthesis of derivative of carbazole with more hydroxyl groups was undertaken and obtained derivative was further used to obtain PU foams with enhanced thermal stability.

\section{EXPERIMENTAL SECTION}

\section{Syntheses}

The synthesis of EPC was performed as previously ${ }^{22}$.

\section{Opening of epoxide ring with sorbitol}

$52.48 \mathrm{~g}(0.235 \mathrm{~mol})$ of EPC and $18.22 \mathrm{~g}(0.1 \mathrm{~mol})$ of sorbitol (pure, POCH Poland, sorbitol: EPC 1: 2.35 molar ratio) were placed in three-necked $100 \mathrm{~cm}^{3}$ flask equipped with reflux condenser, mechanical stirrer and thermometer. The mixture was stirred and heated at $95^{\circ} \mathrm{C}$ to dissolve reagents followed by addition of $6 \mathrm{~cm}^{3}$ triethylamine (TEA, pure, Fluka, Buchs, Switzerland). The temperature of mixture was then increased to $140^{\circ} \mathrm{C}$ and maintained for 35 hours under nitrogen atmosphere. The progress of reaction was monitored by determination of epoxide number. Brown, semi solid resin was obtained upon cooling, from which the volatiles were further removed by vacuum drying at $80^{\circ} \mathrm{C}$.

Analytical results of semiproduct I: 


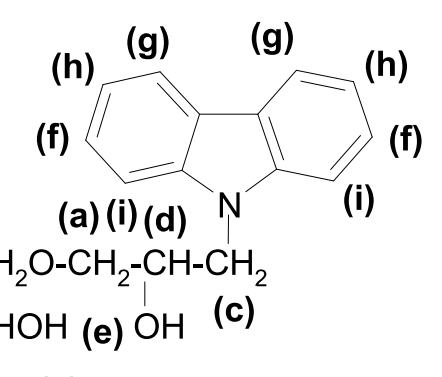

(d) $\mathrm{RO}-\mathrm{CH}$ (e)
(e) $\mathrm{CHOH}$ (d)
(e) $\mathrm{CHOH}$ (d) $\mathrm{OH}$ $\mathrm{CH}_{2} \mathrm{O}-\mathrm{CH}_{2}-\mathrm{CH}-\mathrm{CH}_{2}$ (ab)<smiles>c1ccc2c(c1)[nH]c1ccccc12</smiles>

(l)

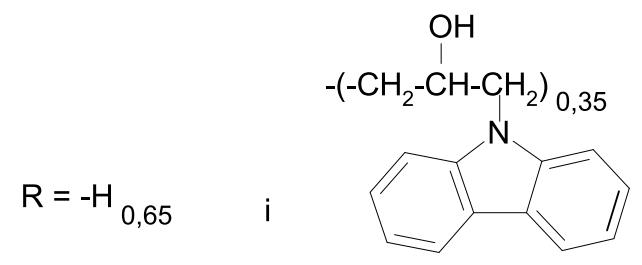

Scheme 1. Structure of semiproduct I

Yield: 83\%; elemental analysis - \% Calcd. C 70.10; H 6.31; N 4.66; \% Found C 69,64; H 6,41; N 4,76; IR $(\mathrm{KBr})\left[\mathrm{cm}^{-1}\right]: 3370(\mathrm{OH}), 3048,3022(\mathrm{Ar}-\mathrm{H}), 2927,2875$ $\left(\mathrm{CH}_{2}\right) 2720(\mathrm{CH}), 1925,1889,1772$ (aromatic overtones), 1627, 1597, 1576 ( $\mathrm{C}=\mathrm{C}$ in carbazole ring), 1491, 1484, $1460(\mathrm{OH}), 14531349\left(\mathrm{CH}_{2}\right), 1326(\mathrm{C}-\mathrm{N}), 1121,1090$, 1063, 1023 (C-O-C and OH), 750, 723 (Ar-H); ${ }^{1} \mathrm{H}-$ NMR (DMSO-d 6 ) [ppm]: a: 3.80-3.95; b: 3.95-4.20; c: $4.20-4.60$; d: 4.60-5.0; e: 5.00-5,40; f: 7.00-7.20; g: 7.20-7.50; h: 7.50-7.75; i: 8.00-8.20.

\section{Reaction oxiranes with semiproduct I}

$14.12 \mathrm{~g}(0.02 \mathrm{~mol})$ of semiproduct I, $0.25 \mathrm{~cm}^{3}(0.001$ mol) TEA and $21.1 \mathrm{~g}(0.48 \mathrm{~mol})$ ethylene oxide (EO, pure, Fluka, Buchs, Switzerland) or $0.5 \mathrm{~cm}^{3}(0.002 \mathrm{~mol})$ TEA and $20.9 \mathrm{~g}(0.36 \mathrm{~mol})$ propylene oxide (PO, pure, Fluka, Buchs, Switzerland) were placed in pressure reaktor of $100 \mathrm{~cm}^{3}$ capacity equipped with magnetic stirrer and thermometer. The mixture was heated at $50^{\circ} \mathrm{C}$ for $11 \mathrm{hrs}$ (in case of EO) or at $90^{\circ} \mathrm{C}$ for $26 \mathrm{hrs}$ (in case of $\mathrm{PO}$ ). The progress of reaction was controlled by determination of epoxide number. The products as brown resins were obtained, which were further heated under reduced pressure $\left(\mathrm{p}=2132 \mathrm{~Pa}, \mathrm{~T}=80^{\circ} \mathrm{C}\right)$ in order to remove the catalyst.

\section{Analytical methods}

The progress of reactions with oxiranes were monitored by determination of epoxide number using hydrochloric in dioxane method ${ }^{23}$. The product formation was also controlled by hydroxyl number (HN) and elemental analysis. Elemental analysis for $\mathrm{C}, \mathrm{H}, \mathrm{N}$, were done with EA 1108, Carlo-Erba analyzer. The IR spectra of products were recorded with Specord 71 IR, Carl Zeiss spectrophotometer in capillary film or in $\mathrm{KBr}$ pellet; the ${ }^{1} \mathrm{H}-\mathrm{NMR}$ spectra were recorded at $500 \mathrm{MHz}$ Bruker UltraShield in DMSO- $\mathrm{d}_{6}$ with hexamethyldisiloxane as internal standard. MALDI ToF (Matrix-Assisted Laser Desorption Ionization Time of Flight) of OGE were obtained on Voyager-Elite Perseptive Biosystems (USA) mass spectrometer working at linear mode with delayed ion extraction, equipped with nitrogen laser working at $337 \mathrm{~nm}$. The method of laser desorption from matrix was used with 2.5-hydroxybenzoic acid in THF at $\mathrm{mg} / \mathrm{cm}^{3}$ concentration. The samples with diluted with methanol to $1 \mathrm{mg} / \mathrm{cm}^{3}$, followed by addition of $10 \mathrm{mg} / \mathrm{cm}^{3} \mathrm{NaI}$ in acetone. Therefore in some cases the molecular ion masses were increased by the mass of $\mathrm{Na}^{+}$and $\mathrm{CH}_{3} \mathrm{OH}$.

Thermal analyses of foams (DTA, DTG and TG) were performed in ceramic crucible at $20-1000^{\circ} \mathrm{C}$ temperature range, about $200 \mathrm{mg}$ sample, under air atmosphere with Termowaga TGA/DSC 1 derivatograph, Mettler. The number-average molecular mass $M_{n}$ of product of reaction EPC with sorbitol was determined cryoscopically in DMSO solvent.

\section{Physical properties of OGE}

Refraction index, density, viscosity, and surface tension of OGE were determined with Abbe refractometer, picnometer, Höppler viscometer (typ BHZ, prod. Prüfgeratewerk, Germany) and by the detaching ring method, respectively.

\section{Preparation of polyurethane foams}

Foaming tests were conducted on laboratory scale in $500 \mathrm{~cm}^{3}$ paper cups at room temperature. In details oligoetherol $(10 \mathrm{~g})$ was mixed with $0.2 \mathrm{~g}$ of Silicone 5340 (pure, Houdry Hülls, USA) as surfactant, TEA as catalyst (0.4-2.4 wt $\%)$ and water $(3 \mathrm{wt} \%)$ with respect to OGE. A calculated portion of polymeric diphenylmethane 4.4'-diisocyanate (pMDI, Merck, Darmstadt, Germany; containing 30-32\% isocyanate groups) was then added and the mixture was vigorously stirred until the contents were creamed. Test samples were cut out from the foams thus obtained.

\section{Characterization of foams}

The following properties of foams were studied: apparent density ${ }^{24}$, water uptake ${ }^{25}$, linear shrinkage estimated on the basis of the change of linear dimension of the sample heated for 4 hours at $100^{\circ} \mathrm{C}^{26}$, thermal stability as the weight loss at 150,175 and $200^{\circ} \mathrm{C}$ within one month and compression strength ${ }^{27}$.

\section{RESULTS AND DISCUSSION}

\section{Synthesis and characteristics of OGE}

The epoxidation was first step of functionalization of carbazole on the route to OGE. The reaction was performed in acetone at $50-56^{\circ} \mathrm{C}$ using six molar excess of epichlorohydrin and two-molar excess of $\mathrm{KOH}$ in relation to carbazole. The reaction mixture was poured into water to obtain crude EPC as cream colored solid as described $\mathrm{in}^{22}$. The compound was subjected to ring opening with sorbitol assuming that both primary hydroxyl groups of 
sorbitol were able to react with EPC according to the following scheme:

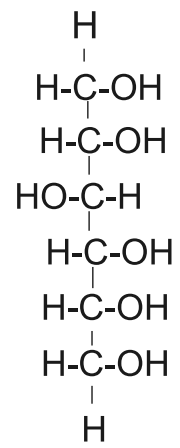

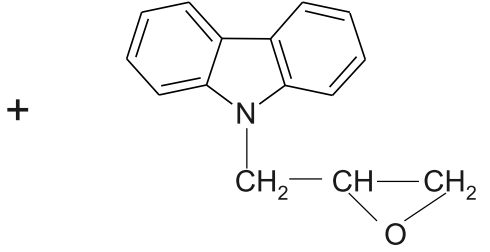

Scheme 2. Reaction of sorbitol with 9-(2.3-epoxypropyl)carbazole

In order to check whether obtained product was suitable reagent for synthesis of OGE, the solubility of compound in oxiranes: EO and PO was tested. The crude product was well soluble in oxiranes, while unreacted sorbitol, which was still present in post-reaction mixture was not. The undissolved solid was isolated and identified as sorbitol by melting point $\left(96^{\circ} \mathrm{C}\right){ }^{1} \mathrm{H}$ -NMR, IR spectra, and elemental analysis (\% exp. C 40.85 ; H 7.85 versus $40,85, \mathrm{H} 7,85$; ufunkcyjne pol $\%$ calc. C 40.55; H 7.74). Indeed the ${ }^{1} \mathrm{H}-\mathrm{NMR}$ spectrum of post-reaction mixture (Fig. 1a) contains characteristic resonances of sorbitol within 4.2-4.6 and 3.3-3.7 ppm regions corresponding to hydroxyl and aliphatic protons. The purification of crude product by dissolving in PO, removal of undissolved sorbitol and evaporation of $\mathrm{PO}$ from filtrate, gave pure product which showed still minor resonances from methylene and methine protons in the ${ }^{1} \mathrm{H}$ NMR spectrum at 3.3-3.7 ppm (compare Fig. 1 a and b), while signal at 3.4 ppm belongs to the overlapped resonances of aliphatic protons of oligoetherol. The resonances of hydroxyl protons in the product remains unaltered in comparison with that of sorbitol

a)

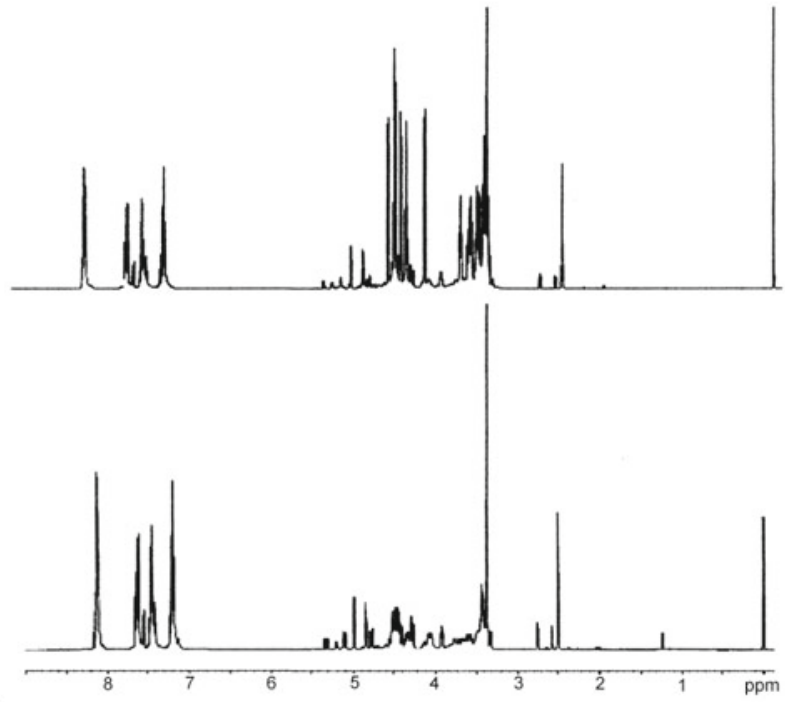

b)

Figure 1. ${ }^{1} \mathrm{H}-\mathrm{NMR}$ spectrum of mixture obtained in reaction of sorbitol with EPC in molar ratio 1:2 (a) and after removal of sorbitol precipitated in PO (b) and the only decrease of intensity of $\mathrm{OH}$ resonance was observed. These spectral observation lead to conclusion that synthesis of oligoetherol requires excess of EPC higher than simple 1:2 sorbitol : EPC stoichiometry. Therefore, considering previous results the synthesis of oligoetherol was then performed at 1:2.35 sorbitol : EPC molar ratio. However, in such conditions the excess of EPC $(0.35 \mathrm{~mol})$ reacts with secondary hydroxyl groups to give the product, which can be described by formula I. The formal stoichiometry can be represented by $\mathrm{C}_{41}$ ${ }_{25} \mathrm{H}_{44 .}{ }_{55} \mathrm{~N}_{2 .}{ }_{35} \mathrm{O}_{8.35}$ formula. Molar mass determined by cryscopic method in DMSO was $702.1 \mathrm{~g} / \mathrm{mol}$, while that calculated was $706.1 \mathrm{~g} / \mathrm{mol}$. Elemental analytical data are in good accordance with the formula. In order to obtain the oligoetherol, the obtained product was mixed with appropriate oxirane and TEA catalyst, heated at $50^{\circ} \mathrm{C}$ (EO) or $90^{\circ} \mathrm{C}(\mathrm{PO})$ to homogenize reaction mixture and initiate the reaction which lasted 11 or 26 hours in case of EO and PO, respectively. The obtained products were OGE of following stoichiometry: sorbitol : EPC : $\mathrm{EO}=1: 2.35: 24$ and sorbitol $: \mathrm{EPC}: \mathrm{PO}=1: 2.35$ : 18 , represented by formula II:<smiles>c1ccc2c(c1)[nH]c1ccccc12</smiles>

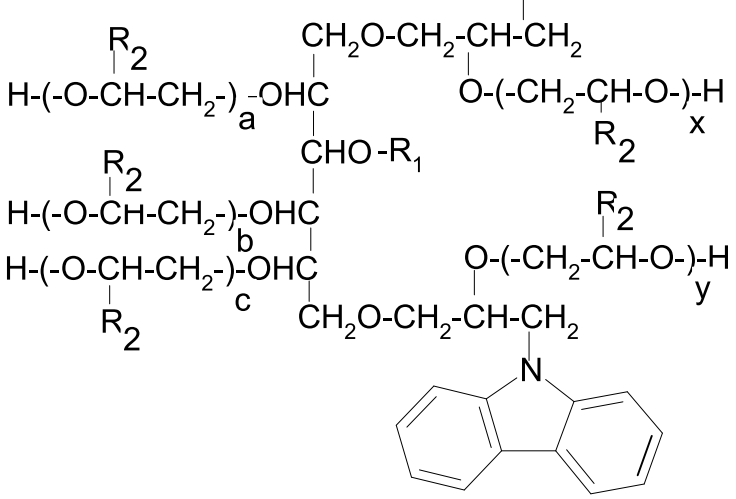

(II) 
where:

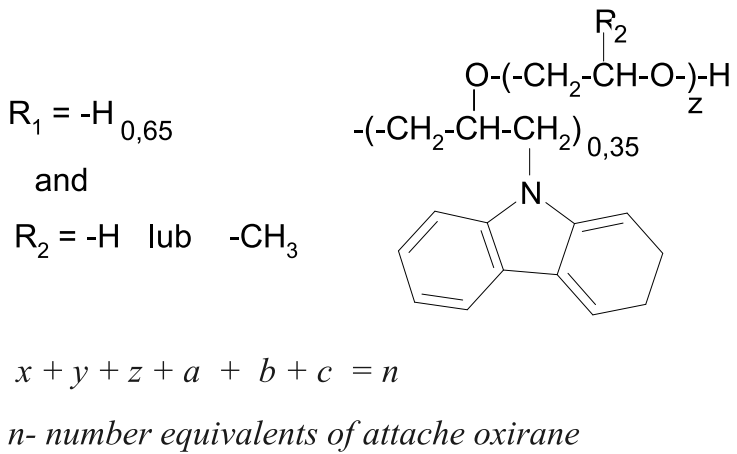

Scheme 3. Structure of oligoetherol

Elemental analysis and HN (Table 2) confirmed the stoichiometry of products obtained from EO: \% calc. C 60.77; H 7.98; N 1,87; \% exp., C 60.65; H 7.92; N 2.05; and from PO: \% calc. C 65.25; H 8.73; N 1.88; \% exp., $\mathrm{C}$ 65.32; H 8.43; N 1.42) as well as IR and ${ }^{1} \mathrm{H}-\mathrm{NMR}$ spectra. In the IR spectrum of the semiproduct obtained from sorbitol : $\mathrm{EPC}=1: 2.35$ (Fig. 2) the bands of $\mathrm{OH}$ groups were observed at $3370 \mathrm{~cm}^{-1}$ and $1020-1200 \mathrm{~cm}^{-1}$, the latter overlapping with $\mathrm{C}-\mathrm{O}-\mathrm{C}$ bands. The bands at $1626 \mathrm{~cm}^{-1}$ the $\mathrm{C}=\mathrm{C}$ stretchings were observed, while that at $1326 \mathrm{~cm}^{-1}$ belongs to $\mathrm{C}-\mathrm{N}$ in carbazole aromatic ring, which suggests the attachment of carbazole to polyhydroxyl alcohol. In the IR spectra of OGE the intensity of bands at $3370 \mathrm{~cm}^{-1}$ decreased, while the opposite effect of intensity was found for the bands at $2867 \mathrm{~cm}^{-1}$ and at $1084 \mathrm{~cm}^{-1}$ obviously due to increase of number of alkyl groups and ether bonds, respectively (Fig. 3). The ${ }^{1} \mathrm{H}-\mathrm{NMR}$ spectrum of the semiproduct obtained from sorbitol : EPC $1: 2.35$ molar ratio shows the presence of resonances both from carbazole ring (7.0-8.2 ppm) and aliphatic protons of sorbitol (at 3.3-3.7 ppm). The

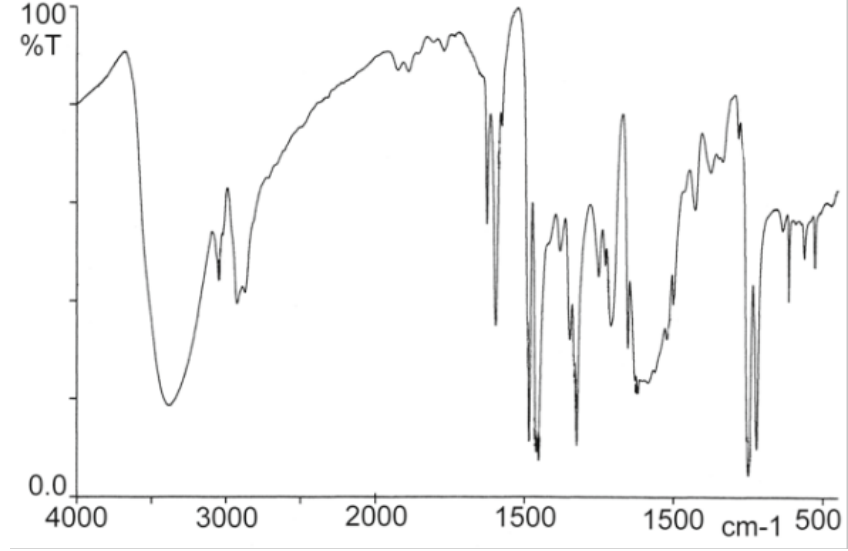

Figure 2. IR spectrum of product obtained in reaction of sorbitol with EPC in molar ratio 1:2.35

hydroxyl proton resonances are observed at 5.0-5.3 ppm. Based on integral intensity of resonances one can conclude that sorbitol was totally consumed with EPC. Upon reaction of the semiproduct with EO the spectrum of product simplifies and only aromatic resonance (within 7.0-8.1 ppm) and aliphatic proton resonances within 3.0-3.9 ppm are observed (Fig. 4). In the spectrum of theproduct obtained from $\mathrm{PO}$, the additional resonances from methyl protons at $0.9-1.1 \mathrm{ppm}$ are present as well as methylene and methine proton resonances at 3.4-3.6 ppm. Further on composition of obtained products was gathered on the basis of their MALDI-ToF spectra. The presence of series of peaks differing of $\mathrm{m} / \mathrm{z}=44$ or 58 (Table 1 , for example entry $4-8,12$ or $10-12,14,15,17-19)$ indicate clearly of incorporation of oxyalkylene subunits into oligomers, originating from EO or PO substrates, respectively. Thus, the products of variable substitution are formed. Moreover the peaks of $\mathrm{m} / \mathrm{z}=487,523,563,599$ and 639 (Table 1 entry

Table 1. Interpretation of MALDI ToF spectrum of oligoetherol obtained in reaction of product sorbitol : EPC $=1: 2.35$ with PO

\begin{tabular}{|c|c|c|c|c|}
\hline Entry & $\begin{array}{c}\text { Signal position } \\
\mathrm{m} / \mathrm{z}\end{array}$ & $\begin{array}{l}\text { Relative intensity } \\
\text { of signal }[\%]\end{array}$ & The molecular ion structure & Calc. molecular weight $[\mathrm{g} / \mathrm{mol}]$ \\
\hline 1 & 430.3 & 100 & $(\mathrm{EPC}+\mathrm{S})+\mathrm{Na}^{+}$ & 429 \\
\hline 2 & 448.3 & 45 & $(\mathrm{EPC}+\mathrm{S})+\mathrm{Na}^{+}+\mathrm{H}_{2} \mathrm{O}$ & 447 \\
\hline 3 & 463.4 & 14 & $(\mathrm{EPC}+\mathrm{S})+\mathrm{Na}^{+}+\mathrm{CH}_{3} \mathrm{OH}$ & 461 \\
\hline 4 & 490.3 & 20 & $(E P C+S)+P O+\mathrm{Na}^{+}$ & 487 \\
\hline 5 & 522.2 & 22 & $(\mathrm{EPC}+\mathrm{S})+2 \mathrm{PO}+\mathrm{H}^{+}$ & 523 \\
\hline 6 & 564.3 & 17 & $(\mathrm{EPC}+\mathrm{S})+2 \mathrm{PO}+\mathrm{Na}^{+}+\mathrm{H}_{2} \mathrm{O}$ & 563 \\
\hline 7 & 600.4 & 10 & $(\mathrm{EPC}+\mathrm{S})+3 \mathrm{PO}+\mathrm{H}^{+}+\mathrm{H}_{2} \mathrm{O}$ & 599 \\
\hline 8 & 638.1 & 15 & $(\mathrm{EPC}+\mathrm{S})+4 \mathrm{PO}+\mathrm{H}^{+}$ & 639 \\
\hline 9 & 691.5 & 1.2 & $(2 \mathrm{EPC}+\mathrm{S})+\mathrm{PO}+\mathrm{H}^{+}$ & 688 \\
\hline 10 & 712.1 & 13 & $(2 \mathrm{EPC}+\mathrm{S})+\mathrm{PO}+\mathrm{Na}^{+}$ & 710 \\
\hline 11 & 769.5 & 12 & $(2 \mathrm{EPC}+\mathrm{S})+2 \mathrm{PO}+\mathrm{Na}^{+}$ & 768 \\
\hline 12 & 843.6 & 10 & $\begin{array}{l}(\mathrm{EPC}+\mathrm{S})+7 \mathrm{PO}+\mathrm{CH}_{3} \mathrm{OH} \\
(2 \mathrm{EPC}+\mathrm{S})+3 \mathrm{PO}+\mathrm{Na}^{+}+\mathrm{H}_{2} \mathrm{O}\end{array}$ & $\begin{array}{l}844 \\
844\end{array}$ \\
\hline 13 & 934.7 & 7.3 & $(3 E P C+S)+P O+N^{+}$ & 933 \\
\hline 14 & 949.6 & 8.7 & $(2 \mathrm{EPC}+\mathrm{S})+5 \mathrm{PO}+\mathrm{CH}_{3} \mathrm{OH}$ & 951 \\
\hline 15 & 1008.6 & 4.9 & $\begin{array}{l}(2 \mathrm{EPC}+\mathrm{S})+6 \mathrm{PO}+\mathrm{CH}_{3} \mathrm{OH} \\
(3 \mathrm{EPC}+\mathrm{S})+2 \mathrm{PO}+\mathrm{Na}^{+}+\mathrm{H}_{2} \mathrm{O}\end{array}$ & $\begin{array}{l}1009 \\
1009\end{array}$ \\
\hline 16 & 1156.7 & 2.8 & $(\mathrm{EPC}+\mathrm{S})+12 \mathrm{PO}+\mathrm{Na}^{+}+\mathrm{CH}_{3} \mathrm{OH}$ & 1158 \\
\hline 17 & 1231.0 & 1.7 & $\begin{array}{l}(2 \mathrm{EPC}+\mathrm{S})+10 \mathrm{PO}+\mathrm{Na}^{+} \\
(3 \mathrm{EPC}+\mathrm{S})+6 \mathrm{PO}+\mathrm{CH}_{3} \mathrm{OH}\end{array}$ & $\begin{array}{l}1233 \\
1233\end{array}$ \\
\hline 18 & 1304.0 & 1.2 & $\begin{array}{l}(2 \mathrm{EPC}+\mathrm{S})+11 \mathrm{PO}+\mathrm{CH}_{3} \mathrm{OH} \\
(3 \mathrm{EPC}+\mathrm{S})+7 \mathrm{PO}+\mathrm{Na}^{+}+\mathrm{H}_{2} \mathrm{O}\end{array}$ & $\begin{array}{l}1300 \\
1300\end{array}$ \\
\hline 19 & 1380.1 & 0.7 & $(2 \mathrm{EPC}+\mathrm{S})+12 \mathrm{PO}+\mathrm{Na}^{+}+\mathrm{CH}_{3} \mathrm{OH}$ & 1381 \\
\hline 20 & 1452.0 & 0.5 & $\begin{array}{l}(\mathrm{EPC}+\mathrm{S})+18 \mathrm{PO}+\mathrm{H}^{+} \\
(3 \mathrm{EPC}+\mathrm{S})+10 \mathrm{PO}+\mathrm{H}^{+}+\mathrm{H}_{2} \mathrm{O}\end{array}$ & $\begin{array}{l}1452 \\
1452\end{array}$ \\
\hline
\end{tabular}




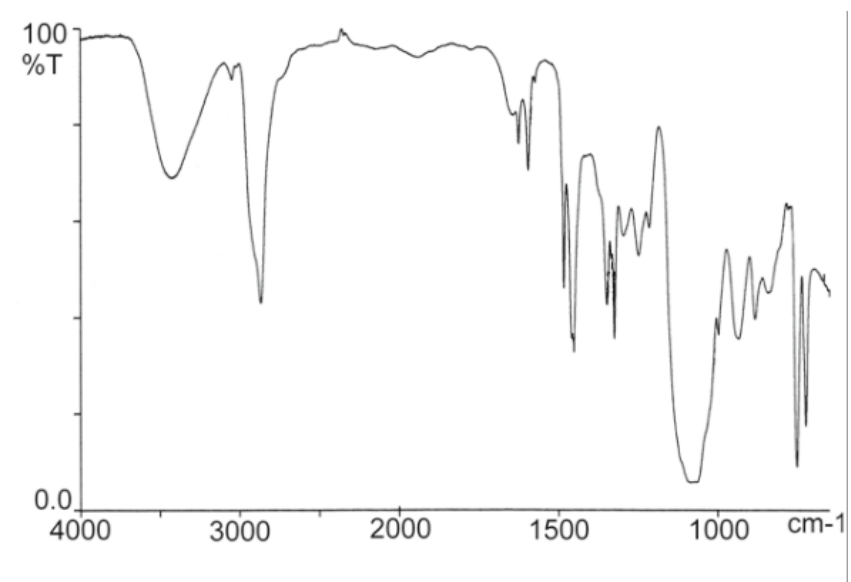

Figure 3. IR spectrum of oligoetherol obtained in reaction of sorbitol with EPC and EO in molar ratio 1:2.35:24

4-8) demonstrates presence of product of 1:1 molar of reaction between sorbitol and EPC; this semiproduct reacts further with oxiranes. Detailed analysis of peaks of $\mathrm{m} / \mathrm{z}>639$ suggests that OGE can also be formed by reaction of oxiranes with semiproducts of $1: 2$ and 1:3 sorbitol: EPC (Table 1 entry 9-20), which is consistent with general formula of oligoetherol II. The following physical properties of obtained OGE were tested: density, viscosity, surface tension and refraction index. All these properties change with temperature quite typically (Table 2). It was found that this kind of oxirane had relevant influence on properties of OGE. It has been noticed that the lower viscosity, density, refraction index and surface tension indicate that these are oligotherols obtained from propylene oxide. These properties are caused by the least packed structure of oligoetherol related to branched oxyalkylene chain caused by the presence of methyl group. The results obtained here suggested that OGE II are suitable for obtaining PU foams. The criteria of substrates were based on surface tension, viscosity and its temperature dependence.

\section{Formation and properties of polyurethane foams}

The obtained OGE were tested on laboratory scale as substrates for PU foams. The optimization of foaming was performed changing the concentration of TEA catalyst, amount of MDI and blowing agent (water). Then the thermal stabililty of foams was determined by mass loss test and changes of mechanical properties

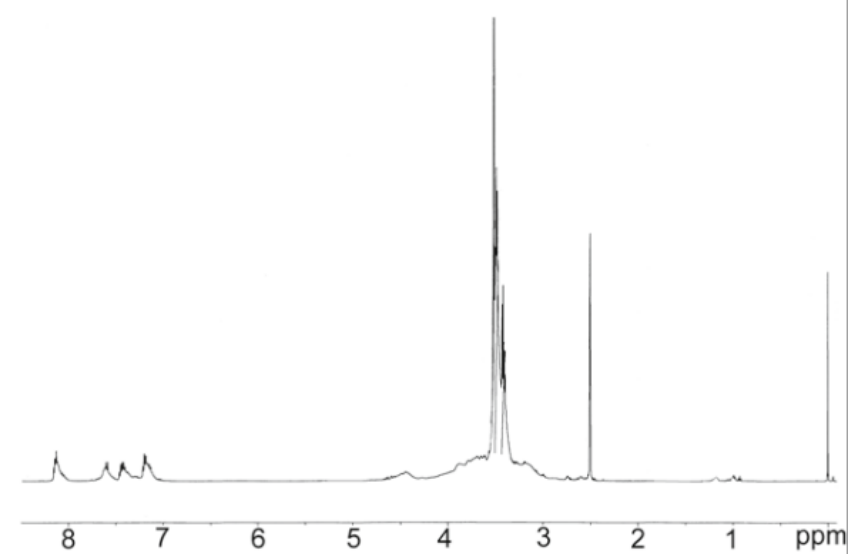

Figure 4. ${ }^{1} \mathrm{H}-\mathrm{NMR}$ spectrum of oligoetherol obtained in reaction of sorbitol with EPC and EO in molar ratio $1: 2.35: 24$

by compression strength. It was found that the best foams, considering the rigidity and pore homogeneity was achieved when amount of isocyanate was $100-120 \mathrm{~g}$ and amount of water was $3 \mathrm{~g}$ per $100 \mathrm{~g}$ of OGE. Isocyanate index was circa 136 for foamed compositions. Cream time was very short $12-18$ seconds) and rise time was also short (within 8-60 s). Tack free time was variable within wide range of time (5s-5 min). Considering the amount of catalyst, which had to be higher in case of products obtained from PO was 2.0-2.4 g per $100 \mathrm{~g}$ of oligoetherol and $0.4-0.8 \mathrm{~g}$ in compositions obtained from EO (Table 3). When these conditions were not met, the foams were not rigid (catalyst deficit), low blowing (water deficit) and irregular pores (water excess). Some properties of foams like apparent density, water uptake and polymerization shrinkage are the same as for classic, commercial PU foams (Table 4). The obtained foams indicated low polymerization shrinkage, usually less than $1.4 \%$. Apparent density was within $50-70 \mathrm{~kg} / \mathrm{m}^{3}$, water uptake was maximum $6.5 \%$. The foams obtained from OGE synthesized from PO showed less water uptake.

Thermal stability of foams was tested by mass loss measurements of samples heated at 150,175 , and $200^{\circ} \mathrm{C}$ (Fig. 5) within one month. The samples before heating and after being heated were tested for compression strength (Table 4). The foams are thermally stable at $150^{\circ} \mathrm{C}$; the mass loss at this temperature is less than $8 \%$ (Fig. 5a). The highest thermal stability has the compo-

Table 2. Some properties of OGE

\begin{tabular}{|c|c|c|c|c|c|c|c|}
\hline \multirow{2}{*}{ Oligoetherol obtained with the use of } & \multirow{2}{*}{$\begin{array}{c}\text { Temperature } \\
{\left[{ }^{\circ} \mathrm{C}\right]}\end{array}$} & \multirow{2}{*}{ Refractive index $n_{D}{ }^{20}$} & \multirow{2}{*}{$\begin{array}{l}\text { Density } \\
{\left[\mathrm{g} / \mathrm{cm}^{3}\right]}\end{array}$} & \multirow{2}{*}{$\begin{array}{l}\text { Viscosity } \\
{[\mathrm{mPa} \cdot \mathrm{s}]}\end{array}$} & \multirow{2}{*}{$\begin{array}{c}\text { Surface tension } \\
{[\mathrm{N} / \mathrm{m}]}\end{array}$} & \multicolumn{2}{|c|}{$\begin{array}{c}\mathrm{HN} \\
{[\mathrm{mgKOH} / \mathrm{g}]}\end{array}$} \\
\hline & & & & & & calc. & found \\
\hline \multirow{7}{*}{ EO } & 20 & 1.5421 & 1.190 & 19216 & 40.4 & 197.2 & 189.5 \\
\hline & 30 & 1.5388 & 1.184 & 8600 & 38.6 & & \\
\hline & 40 & 1.5350 & 1.176 & 3116 & 37.5 & & \\
\hline & 50 & 1.5318 & 1.167 & 1568 & 36.5 & & \\
\hline & 60 & 1.5282 & 1.160 & 1060 & 35.7 & & \\
\hline & 70 & 1.5250 & 1.150 & 366.4 & 34.5 & & \\
\hline & 80 & 1.5228 & 1.136 & 215.5 & 33.1 & & \\
\hline \multirow{7}{*}{$\mathrm{PO}$} & 20 & 1.5212 & 1.117 & 12500 & 35.5 & 198.7 & 190.3 \\
\hline & 30 & 1.5180 & 1.103 & 1928 & 33.0 & & \\
\hline & 40 & 1.5151 & 1.088 & 846.1 & 30.8 & & \\
\hline & 50 & 1.5116 & 1.078 & 402.9 & 28.4 & & \\
\hline & 60 & 1.5086 & 1.067 & 220.2 & 26.5 & & \\
\hline & 70 & 1.5044 & 1.053 & 123.3 & 25.1 & & \\
\hline & 80 & 1.5008 & 1.043 & 72.98 & 23.0 & & \\
\hline
\end{tabular}


sition obtained from oligoetherol synthesized from PO (Table 3, comp. No 1), for which the mass loss is 5.5\%. Its compression strength increases twice upon heating at $150^{\circ} \mathrm{C}$. The compression strength of the sample prepared in analogous way but obtained from EO increases even three times (Table 4). Generally, thermal exposure at $175^{\circ} \mathrm{C}$ causes the mass loss $25 \%$, while exposure of sample to $200^{\circ} \mathrm{C}$ results in $45 \%$ mass loss; in case of the sample of the best thermal stability these values

Table 3. The influence of composition of foaming process are 15 and $30 \%$. Dynamic thermal analysis indicated (Fig. 6) that the foam of best thermal stability occured for the ample obtained from oligoetherol containing oxyethylene units; its decomposition started at $300^{\circ} \mathrm{C}$, while the sample prepared from oligoetherol containing oxypropylene units decomposed starting at $240^{\circ} \mathrm{C}$. Total decomposition occur at $560-580^{\circ} \mathrm{C}$; no further mass loss was observed.

\begin{tabular}{|c|c|c|c|c|c|c|c|}
\hline \multirow{2}{*}{$\begin{array}{l}\text { Oligo-etherol } \\
\text { obtained with } \\
\text { the use of }\end{array}$} & \multirow{2}{*}{$\begin{array}{l}\text { Compo- } \\
\text { siton } \\
\text { number }\end{array}$} & \multicolumn{2}{|c|}{$\begin{array}{l}\text { Composition* } \\
\text { [g/100g ] of } \\
\text { oligoetherol }\end{array}$} & \multicolumn{3}{|c|}{ Foaming process } & \multirow{2}{*}{ Characteristics of foams just prepared } \\
\hline & & $\begin{array}{l}\text { Isocy- } \\
\text { anate }\end{array}$ & TEA & $\begin{array}{c}\text { cream } \\
\text { time } \\
{[\mathrm{s}]}\end{array}$ & $\begin{array}{c}\text { rise } \\
\text { time } \\
{[\mathrm{s}]} \\
\end{array}$ & $\begin{array}{l}\text { tack free } \\
\text { time } \\
{[\mathrm{s}]}\end{array}$ & \\
\hline \multirow{6}{*}{ PO } & 1 & 100 & 2.0 & 14 & 60 & 87 & rigid, small pores \\
\hline & 2 & 116 & 2.4 & 12 & 23 & 300 & rigid, small pores \\
\hline & 3 & 120 & 2.4 & 13 & 40 & 300 & rigid, small pores \\
\hline & 4 & 84 & 1.2 & 18 & 44 & 60 & large pores, underhardened \\
\hline & 5 & 84 & 2.0 & 13 & 44 & 86 & very fragile, large pores \\
\hline & 6 & 84 & 2.4 & 14 & 75 & 25 & large pores \\
\hline \multirow{2}{*}{ EO } & 7 & 110 & 0.8 & 14 & 11 & 5 & rigid, regular pores \\
\hline & 8 & 110 & 0.4 & 14 & 8 & 50 & rigid, regular pores \\
\hline
\end{tabular}

Amount of surfactant $2 \mathrm{~g}$ and water $3 \mathrm{~g}$ per $100 \mathrm{~g}$ of oligoetherols.

Table 4. Some properties of polyurethane foams

\begin{tabular}{|c|c|c|c|c|c|c|c|c|c|c|c|c|}
\hline \multirow{3}{*}{$\begin{array}{l}\text { Oligoetherol } \\
\text { obtained } \\
\text { with the use } \\
\text { of }\end{array}$} & \multirow{3}{*}{$\begin{array}{l}\text { Compo- } \\
\text { sition No }\end{array}$} & \multirow{3}{*}{$\begin{array}{c}\text { Appa- } \\
\text { rent } \\
\text { density } \\
{\left[\mathrm{kg} / \mathrm{m}^{3}\right]}\end{array}$} & \multicolumn{3}{|c|}{$\begin{array}{l}\text { Water uptake } \\
{[\%] \text { after }}\end{array}$} & \multicolumn{3}{|c|}{$\begin{array}{l}\text { Linear dimension stability [\%] at } \\
\text { temperature } 150^{\circ} \mathrm{C} \text { after } 40 \mathrm{~h}\end{array}$} & \multicolumn{4}{|c|}{$\begin{array}{l}\text { Compression Strength } \sigma_{10} \\
{[\mathrm{MPa}]}\end{array}$} \\
\hline & & & \multirow[b]{2}{*}{$\begin{array}{c}5 \\
\text { min. }\end{array}$} & \multirow[b]{2}{*}{$3 \mathrm{~h}$} & \multirow[b]{2}{*}{$24 \mathrm{~h}$} & \multirow{2}{*}{$\begin{array}{l}\text { length } \\
\text { change }\end{array}$} & \multirow{2}{*}{$\begin{array}{l}\text { width } \\
\text { change }\end{array}$} & \multirow{2}{*}{$\begin{array}{l}\text { depth } \\
\text { change }\end{array}$} & \multirow{2}{*}{$\begin{array}{l}\text { before } \\
\text { expo- } \\
\text { sition }\end{array}$} & \multicolumn{3}{|c|}{ after exposition } \\
\hline & & & & & & & & & & $150^{\circ} \mathrm{C}$ & $175^{\circ} \mathrm{C}$ & $200^{\circ} \mathrm{C}$ \\
\hline $\mathrm{PO}$ & 1 & 69.85 & 1.69 & 2.89 & 3.73 & 0.4 & 0.12 & 0.5 & 0.189 & 0.351 & 0.199 & 0.285 \\
\hline EO & 7 & 50.67 & 2.82 & 5.11 & 6.51 & 0.3 & 0.65 & 1.4 & 0.238 & 0.695 & 0.481 & 0.603 \\
\hline
\end{tabular}

a)

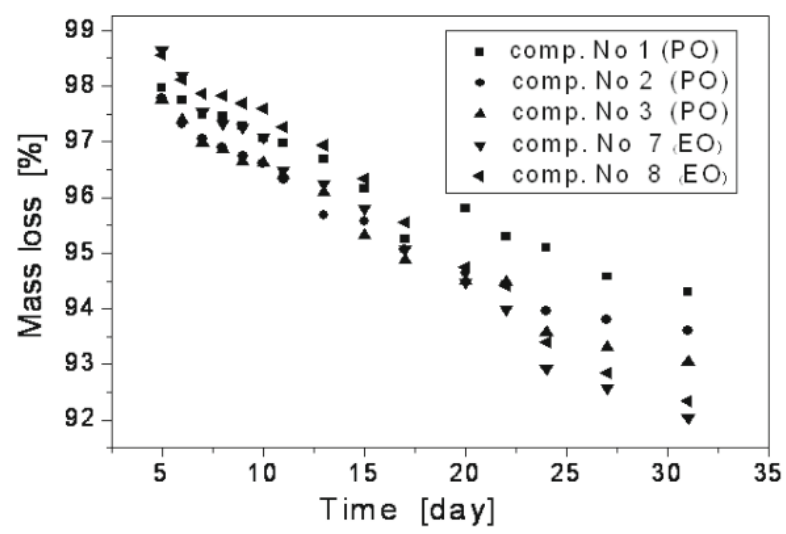

c)

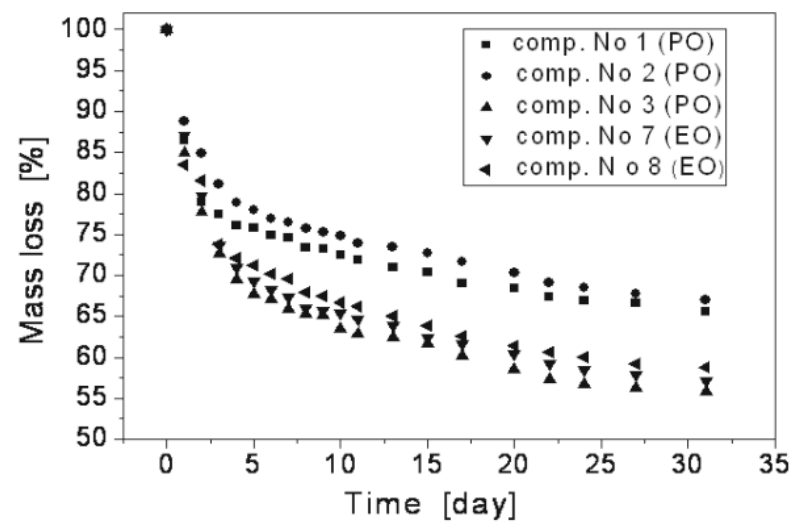

b)

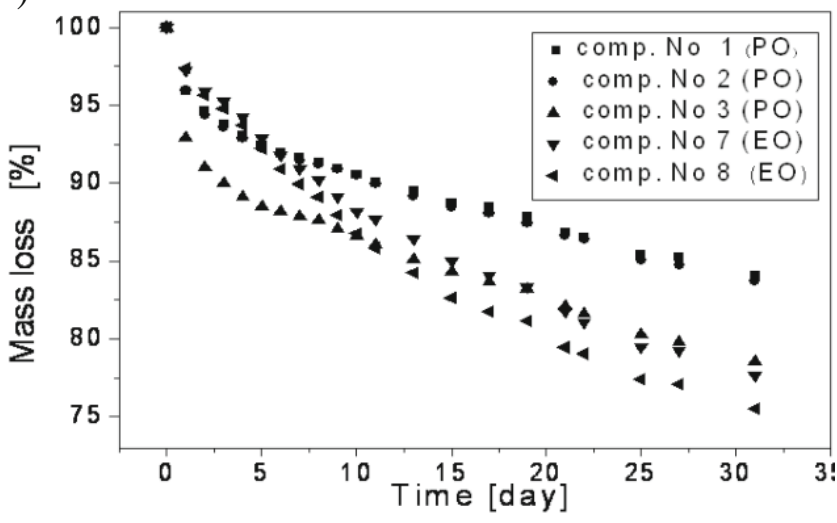

Figure 5. Thermal stability of PU foams as the weight loss after heating at a) 150 , b) 175 and c) $200^{\circ} \mathrm{C}$ for a month (the composition number from table 3 is given in inset) 


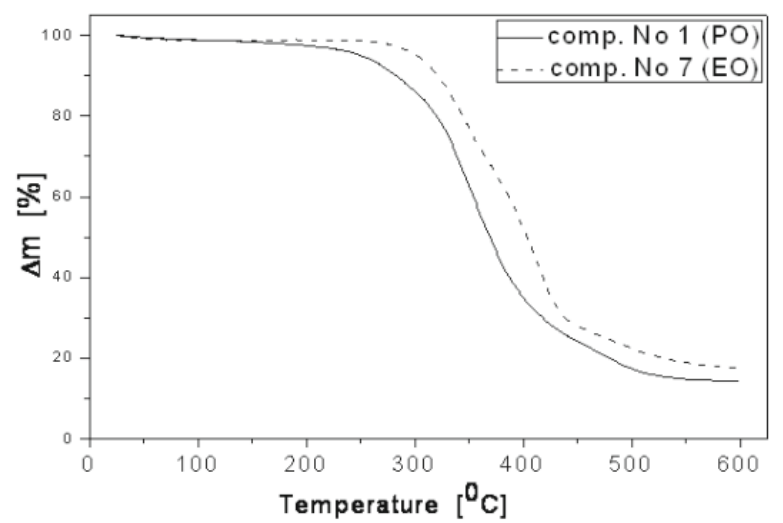

Figure 6. Mass loss of PU foams vs temperature (the composition number from table 3 is given in inset)

\section{CONCLUSIONS}

Hexafunctional OGE with carbazole ring can be obtained from carbazole and glycerine epichlorohydrin to get EPC. Its epoxide ring opening can be performed by reaction with sorbitol; the product can further be converted to oligoetherols by its reaction with oxiranes $\mathrm{EO}$ and PO.

Obtained OGE have similar properties to typical polyols used for PU foam preparation except much higher thermal stability. PU foams obtained form polyfunctional OGE with carbazole ring have remarkable thermal resistance demonstrated by long-time exposure to $200^{\circ} \mathrm{C}$.

\section{LITERATURE CITED}

1. El-Nagger, A.M., Ahmed, F.S.M., Abd El-Salam, A.M. \& El-Gazzar, M.A. (1982). Synthesis and biological activity of some new aminoacylcarbazole derivatives. J. Heterocyc. Chem. 19, 1025-1028. DOI: 10.1002/jhet.5570190509.

2. Nishide, K., Yamanouchi, T. \& Kinjo, K. (1974). Photosensitive material for electro-photography. US Patent 3832172.

3. Renfrew, E.E. (1974). Thiazolylazo- or benzothiazolylazocarbazole dyes for polyester fibers. US Patent 3787178.

4. Shattuck, M.D. \& Vahtra, U. (1968). Photoconductive composition sent. UK Patent 1112458.

5. Spanggaard, H., Jorgensen, M. \& Almdal, K. (2003). Mechanical Strain Sensing in a SIS-Type Elastomer with Single Site Strain Probes Based on Carbazole. Macromol 36, 1701-1705. DOI: 10.1021/ma0256791.

6. Yang, W., Davis, P. \& Drug, P. (1992). Microbial models of mammalian metabolism. Biotransformations of N-methylcarbazole using the fungus Cunninghamella echinulata. Metab. Dispos. 20, 38-46.

7. Kinjo, K., Yamanouchi, T., Kondo, E., Matsuno, H. \& Nishide, K. (1971). Electro-photographic liht-sensitive material. Germ. Patent 2035679.

8. Gratt, J.A. \& Cohen, R.E. (2003). Optical properties of block copolymers containing pendant carbazole groups and in situ synthesized CdS nanoclusters. J. Appl. Polym. Sci. 88, 177-182. DOI: 10.1002/app.11620.

9. Ke, X.J., Yan, X.Z., Srisanit, N., Wang, M., Yang, J.W., Huang, X.F. \& Shong, S.Z. (2003). Holographic storage in carbazole-azo binary compound doped polymer. Optical Comm. 217, 69-74. DOI: 10.1016/S0030-4018(02)02341-6.

10. Lee, J.H., Woo, H.S., Kim, T.W. \& Park, J.W. (2003). Blue organic light-emitting diodes with carbazole-based small molecules. Optical Mater. 21, 225-229. DOI: 10.1016/S09253467(02)00141-6.

11. Monttilier, J.P. (1974). Electrophotograpic photoconductors. Germ. Patent 2360102.
12. Tirapattur, S., Belletete, M., Drolet, N., Leclerc, N. \& Durocher, G. (2003). Steady-state and time-resolved studies of 2,7-carbazole-based conjugated polymers in solution and as thin films: determination of their solid state fluorescence quantum efficiencies. Chem. Phys. Lett. 370, 799-804. DOI: 10.1016/S0009-2614(03)00178-7.

13. Zhang, X.J., Tian, Y.P., Li, S.L., Jiang, M., Usman, A., Chantrapromma, S. \& Fun, H.K. (2003). Zn(II) and Cd(II) $\mathrm{N}$-carbazolylacetates with strong fluorescence. Polyhedron. 22,397-402. DOI: 10.1016/S0277-5387(02)01360-8.

14. Zhu, W. H., Hu, M., Rao, R. \& Tian, H. (2003). A novel family of twisted molecular luminescent materials containing carbazole unit for single-layer organic electroluminescent devices. J. Photoch. Photobio. A 154, 169-177. DOI: 10.1016/ S1010-6030(02)00325-8.

15. Jin, S.H., Sun, Y.K., Sohn, B.H. \& Kim, W. (2000). Synthesis and electro-optical properties of electroluminescent polymers containing carbazole unit. Eur. Polym. J. 36, 957-963. DOI.org/10.1016\%2FS0014-3057\%2899\%2900138-X.

16. Zhang, Y., Wada, T. \& Sasabe, H. (1996). A new synthetic approach to macrocyclic molecules and main-chain polymers containing carbazole moieties. Chem. Comm. 5, 621-622. DOI: org/10.1039/CC9960000621.

17. Lubczak, R. (2008). Oligoetherols and polyurethanes with carbazole ring in side chain. Polimery 53, 587-590.

18. Lubczak, R. (2008). Bifunctional Oligoetherols with Carbazole Ring. J. Appl. Polym. Sci. 110, 3501-3507. DOI: 10.1002/app.28935.

19. Lubczak, R. (2010). Bifunctional Oligoetherols with Carbazole Ring. J. Appl. Polym. Sci. 117, 16-23. DOI: 10.1002/ app.31088.

20. Lubczak, R. (2012). Trifuntional Oligoetherols and Polyurethane Foams with Carbazole Ring. Open J. Org. Polym. Mat. 2, 1-6. DOI: 10.4236/ojopm.2012.21001.

21. Lubczak, R. (2013). Polyester resins with carbazole ring. Polym. Int. 62, 1243-1249. DOI: 10.1002/pi.4415.

22. Lubczak, R. (2006). Diols with carbazole ring and their aza derivatives. Heterocycl. Comm. 12, 201-208. DOI: 10.1016/ S09253467(02)00-141-6.

23. Epoxide resins. Method of testing. Determination of the epoxide number and epoxide eqiuvalent, Polish Standards PN-C-89085-13:1987, Ed. Polish Committee for Standardiza-tion, 1987.

24. Cellular Plastics and Rubbers. Determination of Apparent (Bulk) Density, Polish (European) Standards PN-EN ISO 8452000, Polish Committee for Standardization, 2000.

25. Cellular Plastics, rigid. Determination of Water Absorption, Polish (European) Standards PN-EN ISO 2896-1986, Polish Committee for Standardization, 1987.

26. Cellular Plastics, rigid. Test of Dimensional Stability, Polish (European) Standards PN-EN ISO 2796-1986, Polish Committee for Standardization, 1986.

27. Cellular Plastics. Compression Test for Rigid Materials, Polish (European) Standards PN-EN ISO 844-1978, Polish Committee for Standardization, 1978. 